\title{
The Content of Some Types of Cytokines in Women of Reproductive Age with Exacerbation and Remission of Chronic Herpes Infection
}

\author{
Olga Obukhova, Aleksandr Trunov, Olga Gorbenko, Alya Shvayk, Liliya Trunova \\ Research Center of Clinical and Experimental Medical, Siberian Branch of Russian Academy of Medical Sciences, \\ Novosibirsk, Russia \\ Email: Trunov1963@yandex.ru
}

Received 16 November 2013; revised 7 February 2014; accepted 1 March 2014

Copyright (C) 2014 by authors and Scientific Research Publishing Inc.

This work is licensed under the Creative Commons Attribution International License (CC BY). http://creativecommons.org/licenses/by/4.0/

c) (i) Open Access

\begin{abstract}
There were investigated levels of pro-inflammatory and regulatory cytokines (IL-1 $\beta$, IL-6 and IFN- $\gamma$ ) in women of reproductive age in periods of exacerbation and remission of chronic infection caused by the herpes simplex virus in purpose to study the pathogenetic features of the course of HSV infection. It is shown that both the period of exacerbation, and the period of clinical remission of chronic herpes infection are characterized by increased production of IFN- $\gamma$, IL-1 $\beta$ and IL-6. However, only the mean values of IL-1 $\beta$ were significantly different in periods of exacerbation and remission. Moreover, patients with chronic herpes infection revealed significant heterogeneity of individual values of measured cytokines (IL-1 $\beta$, IL-6 and IFN- $\gamma$ ), which does not depend on the period of clinical disease.
\end{abstract}

\section{Keywords}

Cytokines; Herpes Infection; Chronic Inflammation; Immune Response

\section{Introduction}

The problem of infection caused by the herpes virus, is certainly relevant. The most common pathological conditions are caused by the herpes simplex virus types and 2 (HSV1, 2). There was marked the increase in the frequency of distribution of chronic HSV-infection. More than half of all patients faced with the relapses of the disease [1]-[4]. In addition, at the present time it is proved that the localization of the process has no clear con- 
nection with the type of virus. This fact let us to speak about chronic HSV-infection caused by 1-st and 2-nd type viruses regardless of the localization of the process [5] [6]. Problem remains unclear why the infection does not occur in the complete elimination (eradication) of the virus. Perhaps this "inadequate" response is determined by the biological properties of the virus: its low immunogenicity, the ability for mimicry and "escape" from the immune surveillance. These properties predispose to long-term persistence of the pathogen and the development of a chronic process [7]-[10]. Preservation of the virus in the host (latency) is the cause of recurrent exacerbations of the disease [11] [12].

It remains incomprehensible failure of immune surveillance for recurrent chronic HSV-infection in a full set of antiherpetic immune responses of the host [9] [13]-[15]. Perhaps this is due to the fact that antibodies produced in patients with chronic HSV-infection have weak protective effects. It is also possible that antibodies with the protective effects associate only with a specific antigenic site which may be a latent in herpes virus [16]-[18]. For chronic recurrent HSV-infection, a wavelike course is typical. One of the main causes of acute exacerbations of chronic HSV process considered immunological changes in the system of interferon and cytotoxic cells [7] [19]-[21]. In this case, in more severe HSV infection ability to produce $\alpha / \beta$ and $\gamma$-interferons was reduced [9] [21] [22]. At the same time, there are studies showing that in case of inapparant type of viral process viral replication occurs, perhaps in the cells of the epithelium. It is not detected quantitative and functional deficiency of this or that link of immunity [5] [6]. Moreover, the antigenic stimulation, leads to activation of a humoral link, increased production of proinflammatory cytokines (IL-1 $\beta$, IL-8), IFN- $\alpha$, increasing the number of natural killer cells [18] [23].

Cytokines of the first phase of immune response trigger the cascade of reactions that activates immune recognition and prevent the development of visible lesions of inflammation and generalized reactions [6] [16] [19] [24]. Stage of antigen processing and presentation is very important in the development of immune response [11] [25]. In this regard, an important factor in the study of pathogenesis of chronic HSV-infection is examination of first-phase cytokine levels in the serum of patients [14] [15] [26]. However, studies that reflect the nature of the cytokine production in the period of remission of chronic HSV-infection, represented by single studies [11] [15]. There are data that indicate the presence of viral replication in the epithelial cells during the clinical well-being [1] [5].

Perhaps the activity of the inflammatory process in remission of the pathological process determines the further development of the disease, its severity and the possible emergence of immune disorders. Additionally, in women of reproductive age it may cause the development of pathological processes of the reproductive sphere. Herpes virus is able to spread by all known ways including transplacental. Consequently, the presence of chronic HSV-infection in the mother is a risk factor for the fetus infection and developing of pathological conditions of varying severity [27] [28].

All of the above determines the theoretical and practical importance of studies on the in-depth study of the immunopathogenesis of chronic inflammatory process caused by the herpes simplex virus types 1 and 2 in remission and the comparison of this process with a period of exacerbation.

The aim of this study was to examine the activity of immune reactions of the first phase in women of childbearing age with chronic HSV-infection and the comparison of these reactions in periods of exacerbation and remission of the disease by assessing the levels of certain cytokines in the blood serum.

\section{Materials and Methods}

According to the aim of study on the basis of municipal health care institutions "Novosibirsk Regional Dermatology and Venereal Health center” during the period from February to September 2012 there were examined 94 patients with chronic herpes infection at the age of 19 to 35 years. It has long confirmed the lack of unconditional correlation between the defeat of the urogenital sphere and HSV type 2 virus, and between orofacial and type 1. In this regard, the study included women with chronic herpes infection caused HSV types 1 and 2.

All patients gave informed consent to participate in the study, which is consistent with the ethical standards developed in accordance with the Helsinki Declaration. The surveyed groups were comparable in age.

It was formed by two main groups of patients. Laboratory criteria for inclusion in the study group I and II was the presence of high titers of specific antibodies in antiherpetic examined patients.

The first group (I group) were 49 patients with a diagnosis of the chronic herpes infection caused by HSV1 or type 2 in the acute stage. Inclusion criteria for group I was to confirm the diagnosis of case history, clinical, la- 
boratory and instrumental methods of research. Clinical criteria for inclusion in the study was the presence of group I patients the classical clinical picture (local swelling, redness, itching, vesicular rash). The time from the start of acute illness does not exceed 3 days.

The second group (II group) were 45 patients with a diagnosis of the chronic herpes infection caused by HSV1 or type 2 in remission. Inclusion criteria for group II was to confirm the diagnosis of case history, clinical, laboratory and instrumental methods of research. Also, the criterion for inclusion in the study group II was the lack of specific herpes sores for at least one month prior to the survey, as well as the absence of a period of three months prior to the study of any acute inflammatory diseases of bacterial and viral etiology.

Middle age of patients in first group was 23 years old, and in the second group-29 years old. Exclusion criteria for both groups was the presence of the examined patients of any chronic inflammatory diseases of nonherpetical nature or pathological non-inflammatory processes that can have an effect on the functional state of the immune system. As an exclusion criterion for both groups was the conduction previously immunoactive therapy.

Determination of the concentrations of interleukins-IL- $1 \beta$, IL-6, interferon-gamma (IFN- $\gamma$ ) in serum was carried out using commercial test kits for ELISA produced by "Cytokine" company (Russia) at the manufacturer's instructions. ELISA results were recorded on a vertical photometer "Uniplan" at a wavelength of $450 \mathrm{~nm}$.

The resulting digital data were subjected to statistical analysis and are presented in tabular form. Data analysis was performed using the software package Statgrafics. The significance of the differences in the variation series of unrelated samples was evaluated using the Mann-Whitney test. Data in the tables are presented as $\mathrm{M} \pm \mathrm{m}$, where $\mathrm{M}$ - mean, $\mathrm{m}$ - error of the mean. Considered significant difference between the compared series with a confidence level of $95 \%(\mathrm{P}<0.05)$. As normative there were used own data obtained in the study of cytokine levels of healthy women [29].

\section{Results and Discussion}

When evaluating cytokines in serum of patients groups I and II were detected following patterns, which are presented in Table 1.

Analyzing the table data, it should be noted that IL- $1 \beta$ has significantly higher means in both stages of a pathological process when compared with the standard values. In studying the levels of IL- $1 \beta$ in the examined groups showed a significant difference between the performance of the compared groups $(\mathrm{P}<0.01)$. In group I of patients with exacerbation of HSV infection, level of IL- $1 \beta$ was nearly 9 times greater than normal value (P $<$ 0.001 ), as well as more than two times higher than in remission of herpes infections. In group II, IL- $1 \beta$ level was significantly lower than in exacerbation $(\mathrm{P}<0.01)$. At the same time the level of IL- $1 \beta$ in group II was more than 3 times higher than normal value $(\mathrm{P}<0.001)$. Significant heterogeneity of the index in both groups should be noted. Thus, in patients with acute exacerbation of chronic process level of IL- $1 \beta$ ranged from $3.21 \mathrm{pg} / \mathrm{ml}$ to $1150.04 \mathrm{pg} / \mathrm{ml}$, and in remission—-from $2.12 \mathrm{pg} / \mathrm{ml}$ to $235.21 \mathrm{pg} / \mathrm{ml}$. In both groups, there were persons with a very high score, and with its extremely low values, as well as the level of the indicator corresponding to the adaptive norm.

Heterogeneity of individual values of IL- $1 \beta$ in both groups shows varying macrophage activity level in patients with chronic HSV-infection both at exacerbation and remission. Only some part of patients with

Table 1. Levels of IL-1 $\beta$, IL-6, IFN- $\gamma$ serum in patients with exacerbation and remission of chronic herpes infection.

\begin{tabular}{|c|c|c|c|c|}
\hline & Group & $\begin{array}{c}\mathrm{IL}-1 \beta(\mathrm{pg} / \mathrm{ml}) \\
\mathrm{M} \pm \mathbf{m}(\text { min-max })\end{array}$ & $\begin{array}{c}\text { IL-6 (pg/ml) } \\
M \pm \text { m (min-max) }\end{array}$ & $\begin{array}{c}\operatorname{IFN} \gamma(\mathbf{p g} / \mathbf{m l}) \\
\mathbf{M} \pm \mathbf{m} \text { (min-max) }\end{array}$ \\
\hline $\mathbf{I}$ & $\begin{array}{l}\text { Exacerbation (group I) } \\
\qquad(\mathrm{n}=49)\end{array}$ & $\begin{array}{c}214.44 \pm 40.98^{* * *} \\
(3.21-1150.04)\end{array}$ & $\begin{array}{c}79.49 \pm 8.18^{* *} \\
(24.41-260.03)\end{array}$ & $\begin{array}{c}52.53 \pm 4.79^{* * *} \\
(12.24-134.05)\end{array}$ \\
\hline II & $\begin{array}{l}\text { Remission (group II) } \\
\quad(\mathrm{n}=45)\end{array}$ & $\begin{array}{c}84.40 \pm 13.77^{* * *} \\
(2.12-235.21)\end{array}$ & $\begin{array}{c}61.81 \pm 5.11^{*} \\
(23.41-127.15)\end{array}$ & $\begin{array}{c}58.22 \pm 5.51^{* * *} \\
(18.02-179.04)\end{array}$ \\
\hline \multirow[t]{2}{*}{ III } & $\begin{array}{l}\text { Norm } \mathrm{M} \pm \mathrm{m} \\
(-2 \delta-+2 \delta)\end{array}$ & $\begin{array}{c}23.57 \pm 2.94 \\
(15.99-31.13)\end{array}$ & $\begin{array}{c}25.27 \pm 3.82 \\
(15.23-35.31)\end{array}$ & $\begin{array}{c}35.78 \pm 2.86 \\
(28.67-42.49)\end{array}$ \\
\hline & & $\mathrm{P}_{\mathrm{I}-\mathrm{II}}<0.01$ & $\mathrm{P}_{\mathrm{I}-\mathrm{II}}>0.05$ & $\mathrm{P}_{\mathrm{I}-\mathrm{II}}>0.05$ \\
\hline
\end{tabular}

Note: Norm—own data (Obukhova O.O., Trunov A.N., et al., 2006); significance of the difference: Compared with the norm; ${ }^{*} \mathrm{P}<$ $0.05 ;{ }^{* * *} \mathrm{P}<0.01,{ }^{* * * *} \mathrm{P}<0.001$. 
exacerbation of HSV-infection showed a significant increase of IL-1 $\beta$ (about $25 \%$ ). This could indicate a lack of stimulation by the herpes simplex virus monocytes/macrophages system. At the same time, the presence in group II patients with high values of IL- $1 \beta$ activity shows the activity of inflammation not only in acute, but also in the period of clinical remission. This may be a confirmation of published data on the presence of viral replication in the epithelial cells during the clinical well-being.

It is known that pro-inflammatory cytokine IL-6 is involved in the process of chronization. Moreover, IL-6 is capable of, at certain stages of the inflammatory process, inhibit the synthesis of IL- $1 \beta$ and strengthen the processes of antibody production in the second phase of the immune response. Mean content in serum of patients of group I significantly (more than 3 times) exceed reference values $(\mathrm{P}<0.01)$. The average content of IL-6 in group II was more than 2 times higher than normal, and the excess was also significant $(\mathrm{P}<0.05)$. When comparing the mean values of IL-6 in groups I and II mentioned higher level of IL-6 in acute compared with a period of clinical remission, but this excess was not significant $(\mathrm{P}>0.05)$. The results may be a reflection of the higher intensity of the inflammatory response in acute. However, the activity of inflammatory processes is quite heterogeneous in both groups. This may explain quite distinct individual variation values of IL-6 in comparison groups.

Sufficiently high level of IL-6 could be explained with a point of view of its increased production in chronic infectious processes. However, one should take into account its expression by activated cells of macrophage link in the initial stages of developing an infection or its reactivation. In this case, high levels of IL-6 in group II may be an indication of the presence of viral replication in remission. The consequence of this is the development of an inflammatory response and interrecurrent period.

When outlining the contents of the endogenous immune stimulant IFN- $\gamma$, noted that in the serum of patients in group I, with exacerbation of chronic herpes infection level of IFN- $\gamma$ was at 1.5 times more than normal values of the studied indicator, and this increase was significant $(\mathrm{P}<0.001)$. In group II, level of IFN- $\gamma$ was at 1.6 times more than the normal values, which was also significant $(\mathrm{P}<0.001)$. In analyzing the content of IFN- $\gamma$ between the groups being compared, it was noted that in remission of HSV-infection (II group) it was determined the tendency of the increase of the level of IFN- $\gamma$ compared with exacerbation (I group), but this excess was not significant $(\mathrm{P}>0.05)$.

In analyzing the content individual values of IFN- $\gamma$, it noted the significant heterogeneity in the individual values of the two groups. The maximum values of IFN- $\gamma$ both in exacerbation (group I), and remission of HSV-infection (group II) are almost twice above the required level. This may be a marker of saved high antiviral activity in some patients with chronic HSV-infection. However, in both groups there are patients with very low levels of IFN- $\gamma$, which may be an indicator of failure or depletion of interferon system. This may also be proved by the normative level of the IFN- $\gamma$ in the serum of patients with chronic HSV-infection in acute process.

Thus, the individual immunologic responses both in the period of exacerbation, and during clinical remission of HSV-infection with uniformity of the clinical manifestations are not uniform, which may be connected with the antigenic characteristics of the herpes simplex virus, with the severity of the viral load, and with the individual reactions of organism to the same pathogen.

Summarizing the data obtained, we can draw the following conclusion. At the surveyed women of reproductive age with chronic HSV-infection content of pro-inflammatory cytokines in the blood serum is characterized by increased production of IL- $1 \beta$, IL- 6 and IFN- $\gamma$ compared to the norm, both in the period of exacerbation and in remission of the disease.

Thus only averages IL- $1 \beta$ were significantly higher in acute compared with a period of remission of chronic HSV-infection. When comparing the average indicators during periods of exacerbation and remission of HSV-infection, the significance of the difference for IFN- $\gamma$ and IL-6 was not found.

Obtained data indicate the activity of inflammatory reactions not only during the exacerbation but also in a period of clinical remission of chronic HSV-infection. This may be a confirmation of the presence of viral replication in the epithelial cells during the clinical well-being.

In addition, revealed significant heterogeneity of individual values of examined cytokines-IL- $1 \beta$, IL-6 and IFN- $\gamma$. This heterogeneity is not dependent on clinical period of the disease in patients with chronic HSV-infection and defined both in a group with exacerbation and remission of the disease. The obtained results suggest the presence of some common immunopathogenetic mechanisms of inflammation in a variety of clinical periods of chronic herpes infection. However, the activity of immune reactivity processes is quite heterogeneous within groups comparisons. 
The study was conducted using the equipment access center "Modern optical systems" Research Center of Clinical and Experimental medical, Siberian Branch of Russian Academy of Medical Sciences.

\section{References}

[1] Dubensky, V.V. (2001) Clinico-Epidemiological and Immunological Aspects of Genital Herpes. Immunopatology, Allergy, Infektology, 3, 90-95.

[2] Khaldin, A.A. and Baskakova, D.V. (2007) Epidemiological Aspects of Diseases Caused by the Herpes Simplex Virus (Review). Consilium Medicum, 2, 27-30.

[3] Gupta, R., Warren, T. and Wald, A. (2007) Genital Herpes. Lancet, 370, 2127-2137. http://dx.doi.org/10.1016/S0140-6736(07)61908-4

[4] Yeung-Yue, K.A., Brentjens, M.H., Lee, P.C. and Tyring, S.K. (2002) The Management of Herpes Simplex Virus Infections. Current Opinion in Infectious Diseases, 15, 115-122. http://dx.doi.org/10.1097/00001432-200204000-00003

[5] Samgin, M.A., Khaldin, A.A. and Zuev, A.V. (2006) The Clinical Syndrome of Herpes Polymorphism Dermatological Diseases. Russian Journal of Skin and Venereal Diseases, Appendix: Herpes, 1, 60-66.

[6] Ploegh, H.L. (1998) Viral Strategies of Immune evasion. Science, 280, 248-253. http://dx.doi.org/10.1126/science.280.5361.248

[7] Ketlinsky, S.A. and Ischenko, A.M. (1999) Cytokines and Their Antagonists: Theory and Practice. Medical Immunology, 1, 16-18.

[8] Kaur, A., Sanford, H.B., Garry, D., Lang, S. and Klumpp, S.A. (2007) Ability of Herpes Simplex Virus Vectors to Boost Immune Responses to DNA Vectors and to Protect against Challenge by Simian Immunodeficiency Virus. Virology, 357, 199-214. http://dx.doi.org/10.1016/j.virol.2006.08.007

[9] Cantin, E.M., Hinton, D.R., Chen, J. and Openshaw, H. (1995) Gamma-Interferon Expression during Acute and Latent Nervous System Infection by Herpes Symlex Virus Type I. Journal of Virology, 69, 4898-4905.

[10] Dinarello, C.A. and Pomerantz, B.J. (2001) Proinflammatory Cytokines in Heart Disease. Blood Purification, 19, 314321. http://dx.doi.org/10.1159/000046960

[11] Halford, W.P., Gebhardt, B.M. and Carr, D.J.J. (1996) Persistant Cytokine Expression Intrigeminal Ganglion Latency Infected with Herpes Simplex Virus Type I. The Journal of Immunology, 157, 3542-3549.

[12] Nikitin, V.Y., Zhdanov, K.V. and Sukhina, I.A. (2001) Study of Features of Imunopatogenezis of Latent Forms of Chronic Viral Hepatitis B and C. Medical Immunology, 3, 229-230.

[13] Di Piro, J.T. (1997) Cytokine Networks with Infections: Mycobacterial Infections, Leismsniasis, Human Immunodeficiency Virus Infection, and Sepsis. Pharmacotherapy, 17, 205-223.

[14] Chereshnev, V.A. and Gusev, E.Y. (2001) Immunology of Inflammation: Role of Cytokines. Medical Immunology, 3, 361-368.

[15] Kreisel, J.D., Ricigliano, J., Spruanc, S.L., Carza Jr., H.H. and Hill, J.M. (1997) Neuronal Reactivation of Herpes Simplex Virus May Involve IL-6. Journal of NeuroVirology, 3, 441-448. http://dx.doi.org/10.3109/13550289709031190

[16] Kungurov, N.V., Gerasimova, N.M. and Kuzovkova, T.V. (2001) The Immune Status of Patients with Genital Herpes. Immunology of Urals, 1, 65-66.

[17] Kohl, S. (1992) The Role of Antibody in Herpes Simplex Virus Infection in Humans. Current Topics in Microbiology and Immunology, 179, 75-88. http://dx.doi.org/10.1007/978-3-642-77247-4_5

[18] Whitley, R.J. and Miller, R.L. (2001) Immunologic Approach to Herpes Simplex Virus. Viral Immunology, 14, 111118. http://dx.doi.org/10.1089/088282401750234484

[19] Mikhailenko, A.A. and Fedotova, T.A. (2000) The Role of Mutual Correlations in Assessing the Functionality of the Immune System. Immunology, 6, 59-61.

[20] Mirzoyan, J.V. (2000) State of the Interferon System with Genital Herpes Infection: (Review). Obstetrics and Gynecology, 4, 15-17.

[21] Sainz, B. and Halford, W.P. (2002) Alpha/Beta Interferon and Gamma Interferon Synergize to Inhibit the Replication of Herpes Simplex Virus Type 1. Journal of Virology, 76, 11541-11550. http://dx.doi.org/10.1128/JVI.76.22.11541-11550.2002

[22] Selkov, S.A. and Kokhreidze, A. (2002) Evaluation of Antiviral Resistant Factors in Women with Recurrent Genital Herpes. Medical Immunology, 4, 282-287.

[23] Bussmann, C., Peng, W.M., Bieber, T. and Novak, N. (2008) Molecular Pathogenesis and Clinical Implications of Ec- 
zema Herpeticum. Expert Reviews in Molecular Medicine, 14, 10-21.

[24] Koelle, D.M. and Corey, L. (2008) Herpes Simplex: Insights on Pathogenesis and Possible Vaccines. Annual Review of Medicine, 59, 381-395. http://dx.doi.org/10.1146/annurev.med.59.061606.095540

[25] Medunitsin, N.V. (1995) Processing and Presentation of Antigens by Macrophages. Immunology, 3, 18-21.

[26] Mezentseva, M.V., Narovlianskii, A.N., Ospel’nikova, T.P. and Ershov, F.I. (2002) Cytokine Production by Blood Cells in Herpes, Hepatitis C, and Other Diseases. Voprosy Virusologii, 47, 44-47.

[27] Braun, Z.A. (2001) Neonatal Herpes Simplex Virus Infection in Relation to Asymptomatic Material Infection at the Time of Labor. New England Journal of Medicine, 324, 1247-1252.

[28] Kriebs, J.M. (2008) Understanding Herpes Simplex Virus: Transmission, Diagnosis, and Considerations in Pregnancy Management. Journal of Midwifery \& Women's Health, 53, 202-208. http://dx.doi.org/10.1016/j.jmwh.2008.01.010

[29] Obukhova, O.O., Trunov, A.N., Shvayuk, A.P., Gorbenko, O.M., Obukhov, A.V. and Chornaya, S.M. (2006) Some Aspects of the Immune System of Healthy Donors under the Xenogenic Impact. Medical Immunology, 8, 91-97. 